
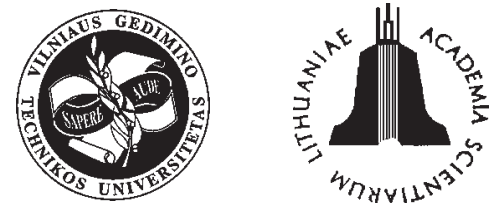

JOURNAL OF CIVIL ENGINEERING AND MANAGEMENT

http:/www.jcem.vgtu.lt

2005, Vol XI, No 4, 299-307

\title{
FURTHER OPPORTUNITIES FOR DEVELOPMENT OF THE METHOD FOR FIRE ORIGIN PROGNOSIS
}

\author{
Donatas Lipinskas, Romualdas Mačiulaitis \\ Vilnius Gediminas Technical University, Saulètekio al. 11, LT-10223 Vilnius, Lithuania. \\ E-mail:d.lipinskas@vpgt.lt,romualdas.maciulaitis@st.vtu.lt
}

Received 08 July 2005; accepted 28 Sept 2005

\begin{abstract}
After fire in buildings investigators start research. The purpose of it is to find the reason of fire, but this thing can be reliably determined only if the fire origin is fixed. The instrumental fire prognosis for wooden structures is currently the most widely applied method in Lithuania. But the analysis of charring of natural wood specimens and the completed tests have revealed some drawbacks of this method, because the method fails to fully estimate the properties of wood and its protection by fireproofing compounds, the impact of the fire load, etc. The obtained test results will help further resolve the problems of reliability of the above-mentioned method.
\end{abstract}

Keywords: fire origin, electric resistance, char depth, charring rate, reliability problems, fireproofing compounds.

\section{Introduction}

In many countries, for the development of low buildings, wood is applied in constructions and roof coverings. In the event of a fire in such buildings, cases of burning that usually manifest themselves as charring of wooden details (construction elements) are noticed.

Thus, investigators of fires make every effort trying to relate such cases with certain important effects of the fire, such as its duration or ways of arising, etc. However, it is worth mentioning here that rules of common character pertaining to the foregoing issue, or scientific discussion is rather limited, because the reasons of fire can be reliably determined only if the fire origin is fixed. This is one of the most difficult problems of fire research [1]. Therefore the fire origin fixing problem remains a topical issue of today. Old methods are verified and improved [2] and new methods are created [3]. New research works in this field put more and more emphasis on the reliability and precision of methods.

The instrumental fire origin fixing method for wooden structures is currently the most widely applied method in Lithuania $[4,5]$. However, the results obtained by this method are not sufficiently reliable, because the method fails to fully estimate the properties of wood and its protection by fireproofing compounds, the impact of the fire load, etc. Whereas the modern fire research is given the task of fixing a fireplace with the maximum possible precision and finding the most accurate data of fire duration and other parameters of the fire development process (ie temperature, fire spreading ways, etc), there is an urgent necessity to improve this method by extending the potentials of its application. So the objective of the present work is to show how it is possible to use charring samples for prediction of the onset of a fire, upon reasonable and thorough study of such samples.

For this purpose the work contains quite a number of cases, pertaining to the charring rate and depth, unusual charring samples and experimental wood charring researches by aiming to establish certain trends and clear up specifics in examination of fires peculiarities related to the foregoing mater and laboratory tests have been performed, which tests used the standard and maximum natural fire conditions enabling to estimate the fire impact duration, the charring rate $(\beta)$ and the effect of other parameters by analysing test specimens of various kinds of natural wood and its samples impregnated with fireproofing compounds (,Flamasep“ and „BAK 1“).

\section{Charring of natural wood specimens}

For quite a long period of time, designers/constructors, willing to calculate the loss of the loading holding capacity of wooden beams after flare-up during a fire, were interested in the charring rates. To receive such data, a considerable number of studies and investigation results, obtained by a typical fire testing device - a fireresistant test furnace were published. Usually such tests are performed by forming fire effect conditions (time/ temperature curve), as it is provided for in ASTM E 119 [6] or ISO 834 [7]. Parameters of the fire resistance test furnace as indicated in these two-type tests are quite similar. 
When exposed to fire, wood (Fig 1) is subjected to thermal destruction (pyrolysis).

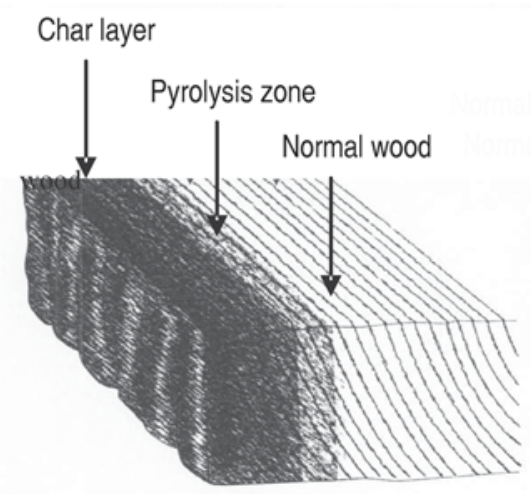

Fig 1. Zones of destruction in the wood cross-section

The process of pyrolysis and burning of wood have been studied extensively. This topic is covered in publications by Schaffer [8], Browne [9], Hadvig [10], PofitSzczepanska [11] etc. Generally, the pyrolysis gas breaks in flames as soon as it rises to the surface of the charred wood. Further burning and mechanical disintegration of the char eventually destroys or severs the external char layer. Generally, the charring rate is almost directly dependent on the time. The charred layer of the wood is formed at approximately $300{ }^{\circ} \mathrm{C}$.

Charring rate is described by means of empirical model based on experimental data (generally, standard fire conditions) and theoretical model based on chemical and physical principles.

In Germany, Lache [12] tested two softwood and three deciduous wood (hardwood) samples and established that the charring rate equaling to the duration of $60 \mathrm{~min}$ ranged within $0,55-0,80 \mathrm{~mm} / \mathrm{min}$. Swiss scientists Frangi and Fontana [13] tested fir beams in ISO 834 thermal furnace, when the exposure in fire time ranged from 30 to $110 \mathrm{~min}$, and fixed the charring rate equal to $0,7 \mathrm{~mm} / \mathrm{min}$, when the thickness of wood of the remaining part exceeded $50 \mathrm{~mm}$; however when the size of the remaining section was less than $50 \mathrm{~mm}$, the charring rate increased in the below indicated procedure:

$$
\beta=2,36-0,036 w
$$

where $\beta$ - charring rate, $\mathrm{mm} / \mathrm{min} ; w$ - remaining section thickness, mm.

The authors [13] did not fix any effect of the density $\rho$ on the wood charring rate, when the density of the wood under investigation was within $340-500 \mathrm{~kg} / \mathrm{m}^{3}$. They also failed to establish any effect of the moisture content $(\mathrm{MC})$ on the charring rate in the presence of moisture values from 8 to $15 \%$. On the other hand, Lache [12] established that in general, when the wood $\mathrm{MC}=20 \%$, the charring rate was by $8,3 \%$ lower if compared when $\mathrm{MC}=8 \%$. Lache also mentioned that the charring rates in the radial, tangent and longitudinal directions, practically, were identical.
In Australia, Syme [14] in the course of 2 hours investigated quite a number of different wood species under the conditions of exposure to fire, similar to ISO 834. However, he failed to establish any specific or peculiar differences of hardwood/softwood (conifers), but determined a certain systemic effect of wood density and produced the following link:

$$
d=\frac{413 \tau}{\rho}+1,6
$$

where $d$ - char depth, mm; $\tau$ - time, min; $\rho$ - density, $\mathrm{kg} / \mathrm{m}^{3}$.

Such formula has been obtained only in respect of high-density specimens, when this index varied from 500 to $900 \mathrm{~kg} / \mathrm{m}^{3}$. Collier [15] performed tests with New Zealand woods and established the charring rates $400-$ $600 \mathrm{~kg} / \mathrm{m}^{3}$ on their specimens, in the presence of $12 \%$ moisture content. In case we use the ratio as applied by Syme, consequently, it is possible to presume the following as regards the foregoing interval of density: the charring rate equals to $0,72-1,10 \mathrm{~mm} / \mathrm{min}$. In the course of tests carried out in Japan [16], under the circumstances similar to ISO 834 exposure to fire, the following charring rates were fixed: $0,67 \mathrm{~mm} / \mathrm{min}$ for Douglas-fir $\left(\rho=565 \mathrm{~kg} / \mathrm{m}^{3}\right)$ and fir $\left(\rho=410 \mathrm{~kg} / \mathrm{m}^{3}\right), 0,74 \mathrm{~mm} / \mathrm{min}$ for the Japanese cedar $\left(\rho=420 \mathrm{~kg} / \mathrm{m}^{3}\right)$. Njankouo et al [17] have tested the hardwood of tropical forests, the density of which reaches $1060 \mathrm{~kg} / \mathrm{m}^{3}$, and have established the undoubted decrease of the charring rate upon increase of the density; however such wood in Europe is not usually used in construction.

White and Nordheim [18], by using a small vertical thermo-camera, performed ASTM 119 tests with different sorts of timber. Upon application of the assessment criteria that the charring starts from $288^{\circ} \mathrm{C}$, they have established that the time period $14,6-15,0$ min was required for charring up $13 \mathrm{~mm}$ depth of the fir or pine if the specimens were tested in the presence of $50 \% \mathrm{RH}$ (relative humidity). In the event of testing specimens under $30 \% \mathrm{RH}$, the charring rate was reduced to $12,1-$ 14,6 min. Accordingly, the time to char through, ie $25 \mathrm{~mm}$, equal to $31-34 \mathrm{~min}$, in the presence of $50 \%$ $\mathrm{RH}$ and 29-33 min in the presence of $30 \%$ RH. Charring rate of hardwood required 10-20\% more time. In the course of investigation they present the empirical model with the following charring rate formula:

$$
\tau=m x_{c}^{1,23}
$$

where $\tau$ - time, min; $m$ - charring rate coefficient; $x_{c}-$ char layer's depth, mm.

The parameter $m$ was not a constant, but it rather depended on factors that included density, moisture content and absolute char contraction. In this case the charring rate coefficient is calculated by the formula:

$$
m=0,000564 \rho+1,21 u+0,532 f_{c}-0,147,
$$

where $\rho$-density of the dried wood, $\mathrm{kg} / \mathrm{m}^{3} ; u$ - moisture content (fraction of oven-dry mass); $f_{c}-$ char reduction factor (dimensionless). 
Dependence of the charring rates on the wood density is also emphasised in Eurocode 5 [19] (Table 1). To determine the charring rate, coefficient $\left(k_{p}\right)$ is applied to certain wood sorts in the capacity of multiplier estimating the specific density of $\operatorname{wood}\left(p_{k}\right) \sqrt{\rho_{o} / \rho_{k}}$, when the density of the tested wood is lower than specified in Table 1. For example, the charring rate for solid softwood with a minimum thickness of $35 \mathrm{~mm}$ and specific density of less than $290 \mathrm{~kg} / \mathrm{m}^{3}$ should be multiplied by coefficient $k_{p}$ calculated by the formula:

$$
k_{p}=\sqrt{\frac{290}{\rho_{k}}},
$$

where $\rho_{k}-$ specific density of wood, $\mathrm{kg} / \mathrm{m}^{3} ; k_{p}$ - coefficient.

Table 1. Charring rates $\beta_{\mathrm{o}}$ for timber

\begin{tabular}{l|c}
\hline \multicolumn{1}{c|}{ Timber } & $\begin{array}{c}\beta_{o} \\
\mathrm{~mm} / \mathrm{min}\end{array}$ \\
\hline $\begin{array}{c}\text { a) Softwood } \\
\text { Solid timber with a specific density of } \geq\end{array}$ & \\
$\begin{array}{l}290 \mathrm{~kg} / \mathrm{m}^{3} \text { and a minimum thickness of } 35 \mathrm{~mm} \\
\text { Glued laminated timber with specific density }\end{array}$ & 0,8 \\
of $\geq 290 \mathrm{~kg} / \mathrm{m}^{3}$ \\
$\begin{array}{l}\text { Wood panels with specific density of } \\
450 \mathrm{~kg} / \mathrm{m}^{3} \text { and thickness of } 20 \mathrm{~mm}\end{array}$ & 0,7 \\
$\begin{array}{l}\text { b) Solid or glued laminated hardwood with } \\
\text { specific density of } \geq 450 \mathrm{~kg} / \mathrm{m}^{3} \text { and oak }\end{array}$ & 0,9 \\
$\begin{array}{l}\text { c) Solid or glued laminated hardwood with } \\
\text { specific density of } \geq 290 \mathrm{~kg} / \mathrm{m}^{3}\end{array}$ & 0,5 \\
\hline
\end{tabular}

From the submitted analysis it is possible to draw the following conclusion: in ASTM E 119/ISO 834 tests, the researches of the influence of the wood density on the charring rate were rather inconsistent and contradictory. Irrespective of the fact that in quite a number of different countries species of wood used for construction usually distinguish for a narrow density range, the matter pertaining to the unified method for calculation of the charring rate is rather complicated and problematic and has not been solved up to now.

Situation of investigations of the charring rate of wood with fireproofing compounds is still more complicated, because too little attention is paid to the charring processes of wooden structures protected by fireproofing compounds. Fireproofing compounds are used in order to reduce the spread of flame over the surface and into the depth of wood, thus reducing the wood charring rate. Charring rate is not sufficiently studied in this respect. This is undoubtedly conditioned by the large amount of various fireproofing compounds and various reactions to the impact of high temperatures. Reference source [20] analyses the impact of a fireproofing compound capable of increasing the charring resistance of wood. It has been established that the effect of the wood fireproofing compound on the charring rate consists in the fact that the compound extends the period of time until the wood bursts into flames, thus reducing the spread of flame and increasing the charring resistance of wood. Meanwhile, herein a task is set to determine how impregnation of the tested wood with fireproofing compounds may influence the final results of the forecast.

\section{The essence of the instrumental method designed for fixing a fireplace}

A wood charcoal research method $[4,5]$ is currently used in Lithuania, based on simultaneous estimation of the physical and chemical properties of charcoal and the depth of wood charring at the place of charcoal sampling. Some other particulars of charcoal are also emphasised which indicate specific conditions of its formation by measuring resistance of charcoal $(R, \Omega)$. In the course of charring processes at the time of the fire, charcoal resistance reduces gradually from $10 \mathrm{G} \Omega$ to $1 \Omega$ units. The essence of the method consists in taking charcoal samples from the places, which according to the signs of burning and heat impact could be the original fireplace or a zone of sustained smouldering, as well as from other deepest charred places of wooden structures. Of course, the charcoal layer $\left(\mathrm{H}_{\mathrm{y}}, \mathrm{mm}\right)$ of the charred wooden structure, the depth of the burned structure $\left(\mathrm{H}_{\mathrm{n}}, \mathrm{mm}\right)$ and the thickness of the original structure (H, mm) should be measured prior to the above sampling. Charcoal specimens taken from the place of fire should be dried in the laboratory drier at $100{ }^{\circ} \mathrm{C}$. Then the electric resistance $(R, \Omega)$ of each charcoal specimen shall be measured using the specially designed equipment (Fig 2) created by VNIIPO experts [4, 5].

Dependencies $(6,7)$ derived by the empiric method enable to draw the final conclusion by forecasting the temperature and the time of its impact at each place where charcoal samples have been taken.

$$
T=\frac{4540}{\ln \frac{B \cdot H \cdot P}{10-P}+2,15},
$$

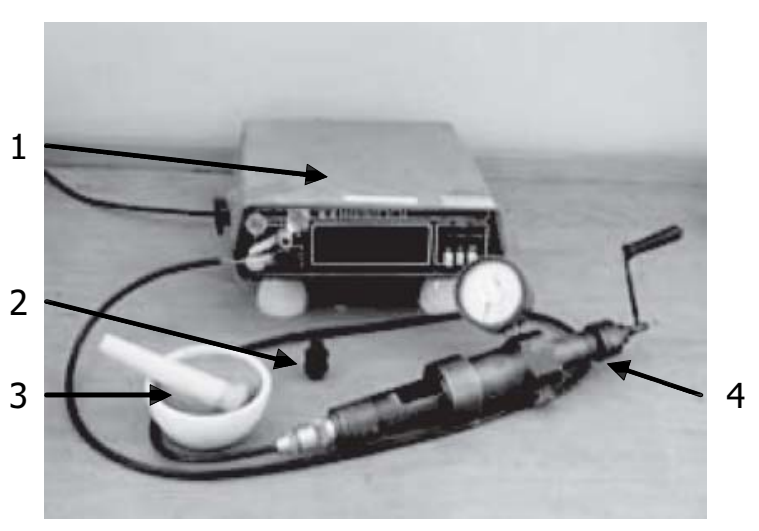

Fig 2. Equipment for measuring the electric resistance of charcoal: 1 - multi voltmeter, 2 - press form, 3 - pestle, $4-$ press 


$$
\tau_{g}=\exp \left(1,38 \cdot \ln B \cdot H+0,38 \cdot \ln \frac{P}{10-P}-1,19\right),
$$

where $B$ - coefficient estimating the thickness of the structure and kinetics of the charring process; $H$ - wood charring depth, mm; $P$ - decimal logarithm of the charcoal specimen's specific resistance.

\section{Testing methods and tested materials}

\subsection{The special one-side heating equipment}

In order to determine the difference of the charring rates of various sorts of wood protected and not protected with fireproofing compounds and their effect on the final forecast result, special equipment was used for one-side heating of the structures according to reference source $[21,22]$. Such equipment ensures simulation of the one-side heating of the test sample. This equipment (Fig 3) consists of the following parts: heater for oneside heating of structures, heat regulator, measuring devices and the equipment for registration of their readings.

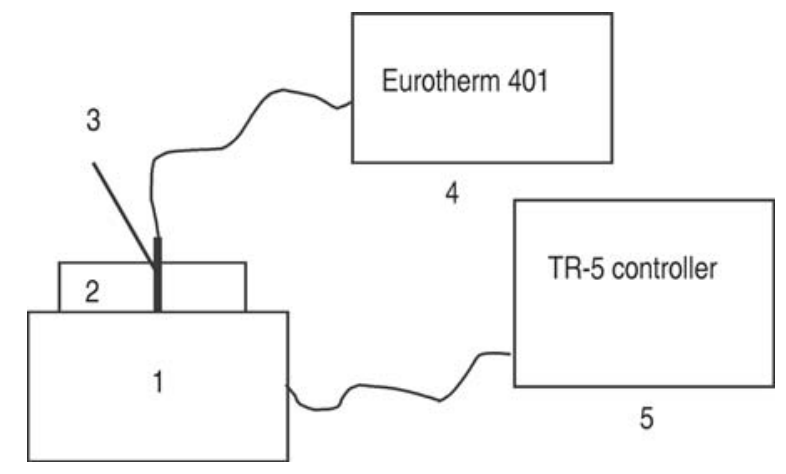

Fig 3. The principal scheme of the one-side heating equipment that has been used for one side heating tests [21]: 1 - the one-side heating apparatus; 2 - fragment of the tested structure; 3 - the temperature and heat flow measuring equipment; 4 - the Eurotherm 401 recorder; 5 the TR-5 controller for regulation of temperature in the heating chamber

All structure fragments tested by one-side structure heating method (Fig 3, 1) had dimension of $300 \times 300$ $\mathrm{mm}$, and their thickness varied from 35 to $70 \mathrm{~mm}$.

Temperature was measured with $\mathrm{K}$ type thermocouples ( $\mathrm{Ni} \mathrm{Cr}-\mathrm{Ni} \mathrm{Al}$ ) of $0,8 \mathrm{~mm}$ diameter, the measuring error of which within the temperature range from -40 to $+375^{\circ} \mathrm{C}$ was $1,5{ }^{\circ} \mathrm{C}$, and within the range of $375-1300{ }^{\circ} \mathrm{C}$ the measuring error was $0,4 \%$. The temperature measuring thermocouples of such design are provided for in ISO 834 Standard [7].

Eurotherm 401 type automatic recorder recorded readings of all thermocouples mounted on the tested sample. It records temperature readings at $1 \mathrm{~s}$ intervals. The software of this equipment enables to present the obtained results in the form of tables or (temperature-time) curves.
The experiment was based on the principle of heating the sample from one side according to strictly regulated temperature-time relationship, with the following measurements of the depth and electric resistance of charcoal by means of specially (Fig 2) designed equipment.

The above-mentioned equipment ensures the heat load (temperature in the heating chamber) selected for the tests. The heat load for the tests was selected in accordance with the temperature-time relationship of a standard fire simulating the post-flashover stage the mathematic expression of which is as follows [7]:

$$
T_{f}-T_{0}=345 \lg (8 \tau+1),
$$

where $T_{f}$ and $T_{0}$ are the temperature in the heating chamber and the initial test temperature, ${ }^{\circ} \mathrm{C}$, respectively; $\tau$ is the testing time, min.

Tests of fire-resistant properties of structures based on this dependency are also performed in various countries all over the world. In case of the selected temperature-time relationship the initial temperature increased at the rate of approx $100{ }^{\circ} \mathrm{C} / \mathrm{min}$.

\subsection{SBI test method}

It is a completely new testing method (Fig 4) that imitates fire conditions for big construction elements, maximally approaching them to real circumstances.

Harmonisation of fire safety standards in Europe forced to create a completely new test of combustibility of construction products (average scale): Single Burning Item, ie SBI test. The majority of construction products, manufactured and sold in Europe, are tested and classified according to combustibility thereof, by applying EN 13823 SBI testing method [23].

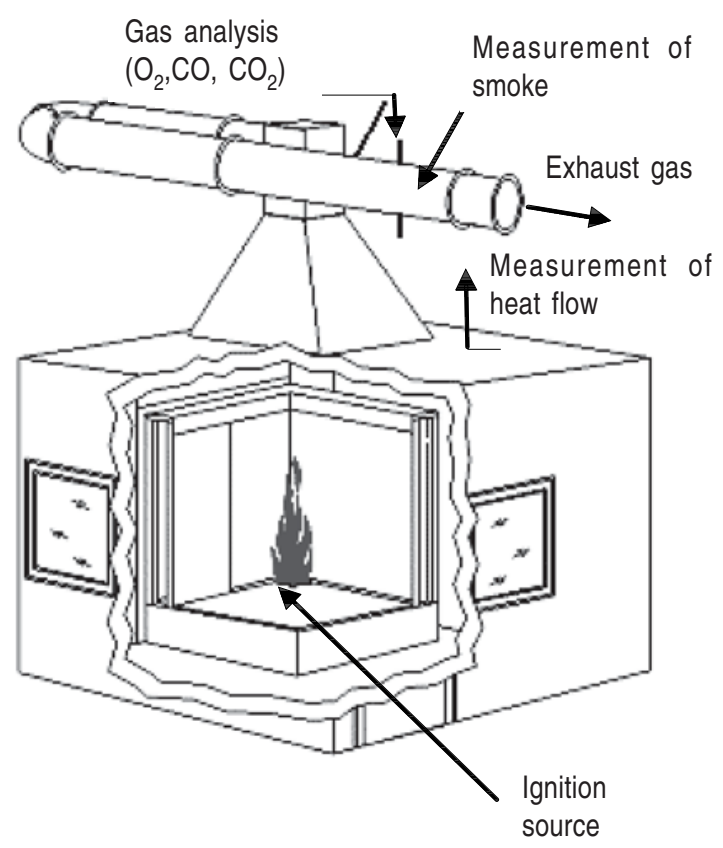

Fig 4. SBI testing equipment scheme 
In the course of SBI testing, a specimen is under thermal exposure of the $(30,7 \pm 2,0) \mathrm{kW}$ capacity burner, located underneath the angle.

Flames of the fire are created by burning the propane gas that is admitted through a sand box. A specimen is placed in a trolley below the ejection system. A specimen consists of two vertical wings that make up an angle. The short wings has got the following dimensions: $(495 \pm 5) \mathrm{mm} \times(1500 \pm 5) \mathrm{mm}$, while the long wing is of the below indicated dimensions: $(1000 \pm 5) \mathrm{mm} \times$ $(1500 \pm 5) \mathrm{mm}$. Measurements of the combustion chamber are as follows: $3 \mathrm{~m} \times 3 \mathrm{~m}$, while the total equipment height is approximately $4,2 \mathrm{~m}$. The test duration is $20 \mathrm{~min}$ (in case of necessity the testing time may be increased). Emission gas is eliminated from the system by compulsory extraction. The majority of measurements is performed in the measurement section that is located in the ejection tube.

By using the foregoing testing method, it is possible to establish the below listed principal combustibility indices: FIGRA (Fire Growth Rate Index), SMOGRA (Smoke Growth Rate Index), TSP (Total Smoke Amount), LFS (Lateral Flame Spread along the long specimen wing), THR (Total Heat discharged by the specimen within a certain period of time as of the beginning of action thereof of the main burner flame), etc. Indices of the heat and smoke discharge speed and amount shall be measured by appropriate devices, while physical characteristics thereof are evaluated by visual observation.

Application of the foregoing method allows the establishment of combustibility in the below listed construction products: impregnated wood, wood-wool panels, heat insulated decoration panels/boards (with filler of mineral cotton-wool, polystyrene, polyurethane and cellulose fibre), decoration surfaces covered with paint, PVC tubes, multi-layer panels/boards (with layers of mineral cotton, stone cotton, polystyrene and polyurethane), etc. The foregoing method will also be used in our investigations by aiming to establish, as accurately as possible, the charring rate of the wood specimens, maximally approached to real conditions, and comparing the results obtained upon application of different test methods.

\subsection{Tested materials and their characteristics}

Fragments of structures made of two sorts of wood: softwood (pine and fir) and hardwood (oak and ash) protected and not protected with fireproofing compounds were used for the tests. „Flamasep“ or „BAK 1“ fireproofing compound was used as protector. Specimens of the established size $(300 \times 300 \mathrm{~mm})$ (Fig 5, a) were soaked in the „Flamasep“ solution for $10 \mathrm{~h}$, then dried in natural conditions until the moisture content of specimens reached the value necessary for the tests, ie not exceeding $15 \%$. Density of the non-impregnated pine was $455 \mathrm{~kg} / \mathrm{m}^{3}$, fir $-435 \mathrm{~kg} / \mathrm{m}^{3}$, oak $-720 \mathrm{~kg} / \mathrm{m}^{3}$, and ash $680 \mathrm{~kg} / \mathrm{m}^{3}$.

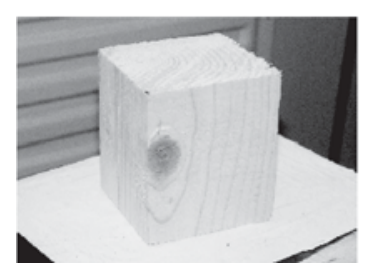

a)

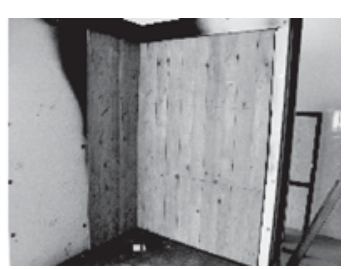

b)
Fig 5. The below listed materials were used in the tests: $\mathrm{a}$ - natural wood specimen (pine); $\mathrm{b}$ - pine boards tested by applying SBI testing method (25 mm thickness) with fireproofing compound BAK 1 and without it

By applying SBI method (Fig 5, b), $25 \mathrm{~mm}$ thickness pine boards were used; they were impregnated with fireproofing compound BAK 1 and without it.

\section{Test results and discussion}

It has been established that under the circumstances of standard fire the charring rate of softwood is $0,8 \div 0,9 \mathrm{~mm} / \mathrm{min}$, the charring rate of hardwood and impregnated softwood is $0,5 \div 0,6 \mathrm{~mm} / \mathrm{min}$, and the charring rate of impregnated hardwood is $0,3 \div 0,4 \mathrm{~mm} / \mathrm{min}$. We see (Fig 6) that the charring rate of different sorts of wood is different, whereas the efficiency of fireproofing compounds used for impregnation of wood is marked with respect to the charring rate.

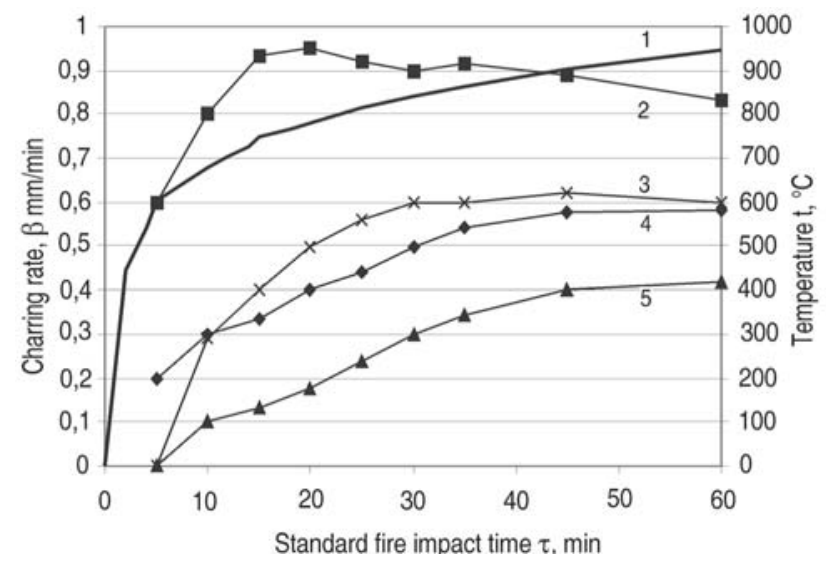

Fig 6. Temperature (1) and charring rate (2-5) of different varieties of wood protected and not protected with „Flamasep" fireproofing compounds in relation to time characteristics under the circumstances of standard fire: 1 - standard fire curve, 2 - pine, 3 - impregnated pine, 4 - oak, 5 - impregnated oak

Differences of the charring rate between the wood samples of the same sort (between pine and fir, or between oak and ash) are insignificant and are within the above-mentioned limits of charring rate.

The charring rate data obtained during the tests were practically identical to the charring rates of softwood and hardwood presented in Eurocode 5 [19] (Table 1). Here softwood with the density of $\geq 290 \mathrm{~kg} / \mathrm{m}^{3}$ has $\beta_{o}=0,8 \mathrm{~mm} / \mathrm{min}$, and hardwood with the density of 
$\geq 450 \mathrm{~kg} / \mathrm{m}^{3}$ has $\beta_{o}=0,5 \mathrm{~mm} / \mathrm{min}$. From the results obtained in the course of the test, it is possible to see the wood density impact on the wood charring which can be expressed by such empirical expression that is practically very similar to received to the dependence as given by the Australian scientist Syme (2):

$$
d=\frac{387 \tau}{\rho},
$$

where $d$ - char depth, mm; $\tau$ - time, min; $\rho$ - density, $\mathrm{kg} / \mathrm{m}^{3}$.

Thus we made sure that the test equipment used for testing the impact of standard fire on fragments of wooden structures is absolutely suitable for the purpose, and the results are sufficiently reliable.

However, further wood charring investigations by using SBI method equipment lead to correction of the values of the charring depth and also the wood charring values that were obtained earlier because it has been noticed that irrespective of the type of wood and whether it is protected with antipirens or not, the charring process is yet more active by $20 \%$ as in the course of a $25-\mathrm{min}$ period the charring rate of pine boards equal to $0,95 \div 1,1 \mathrm{~mm} / \mathrm{min}$, while the impregnated pine boards in the course of a 30-min period charred at the rate of $0,6 \div 0,75 \mathrm{~mm} / \mathrm{min}$. So the comparative data (Fig 7) of the charring depth in respect of time as obtained by applying SBI method and special single-sided construction heating equipment are offered.

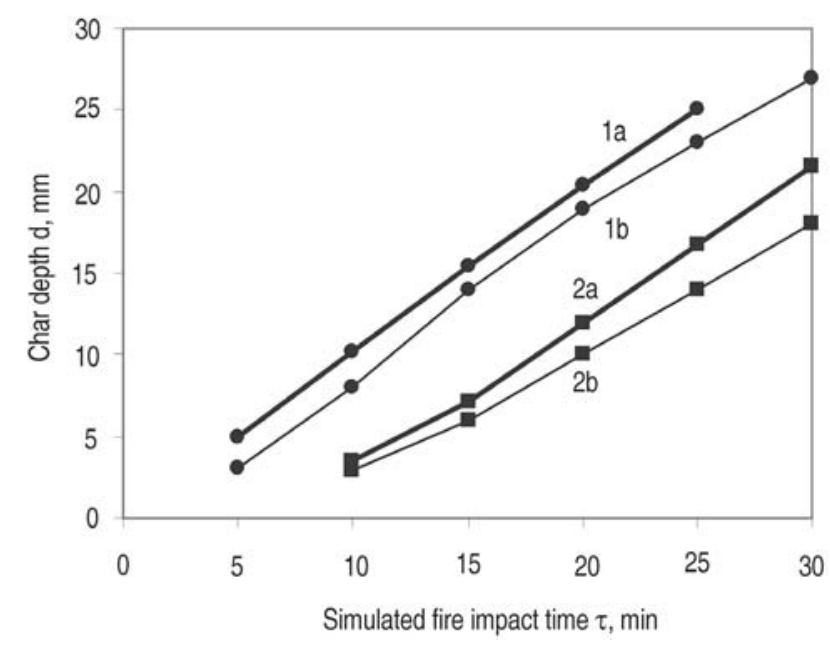

Fig 7. Dependence of the charring depth of wood upon the time, tested by applying different methods: 1 - pine; 2 - pine protected with fireproofing compound "BAK 1", a - SBI method; b - special single-sided constructions heating equipment

Undoubtedly, such differences occur due to additional amount of oxygen as SBI method goes on maximally in the natural surroundings, sizes of specimens are also, at the maximum, of the natural size. Thus, it is necessary to introduce a certain correction $(k=1,2)$, allowing the evaluation of the amount of oxygen under test conditions, by forecasting the experimental data of ther- mal chamber, complying with the conditions as established by ISO 834 . In the foregoing case the dependence (9) of the wood charring obtained by us will be as following:

$$
d=\frac{387 \tau}{\rho} \cdot k,
$$

where $d$ - char depth, mm; $\rho$ - density, $\mathrm{kg} / \mathrm{m}^{3} ; k-$ coefficient evaluating the amount of oxygen $(\mathrm{k}=1,2)$; $\tau$ - time, min.

By using the same testing equipment [22], tests of charring of different wood species, performed by us quite recently, when the specimen are exposed lengthwise of wood, showed that anisotropy media had influence the wood charring, the foregoing fact may be proved by samples given in Fig 8. It has been established by tests that the average charring rate of softwood in the direction of its growing equals to $1,2 \mathrm{~mm} / \mathrm{min}$; while that of hardwood is $0,8 \mathrm{~mm} / \mathrm{min}$. Moisture content of the used wood specimens did not exceed $15 \%$. Consequently, it is clear that the values of the charring rate along the direction of wood growing increase. Thus, the results obtained by Lache [12] and us, in fact, are different. Upon evaluation of the above-mentioned correction coefficient, under the conditions of natural fire, the charring rate along the wood growing direction will be about $20 \%$ higher.

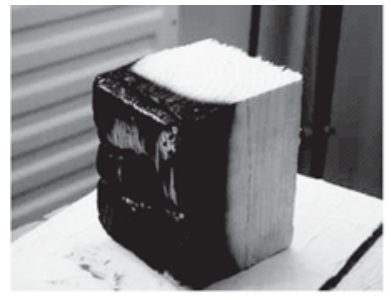

a)

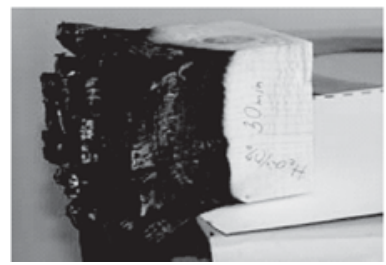

c)

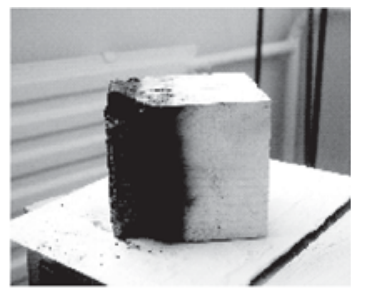

b)

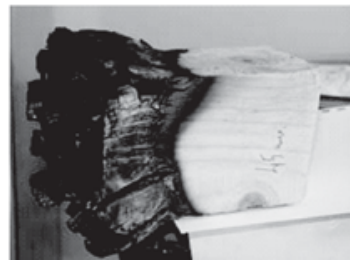

d)
Fig 8. Tests of wood (pine) charring under typical fire conditions: $\mathrm{a}$ and $\mathrm{b}-$ perpendicularly and lengthwise of wood accordingly after $15 \mathrm{~min}, \mathrm{c}$ - lengthwise of wood after $30 \mathrm{~min}, \mathrm{~d}-$ lengthwise of wood after $45 \mathrm{~min}$

The different charring rates (Fig 6) obtained in the course of experiment give ground for thinking that the forecast of the temperature value and fire duration for wooden structures performed by using the fire origin fixing method $[4,5]$ will differ as well.

Our tests have been performed under the circumstances of a standard fire; therefore, the temperature forecast by the above-mentioned method is not absolutely 
accurate. The heat load on the structure surface and alternation of the load value in accordance with the duration of heating has effect on the charcoal electric resistance value intended for temperature estimation and on the wood charring rate. This topic is discussed in the works of Butler [24] and Koszyk [25], and in the works of White $[26,27]$. Calculation methods of high temperatures dividing within the structural components are presented in work of Lukošius [28]. It is maintained in the works $[4,5]$ that the electric resistance of the charcoal obtained at higher temperatures is lower. We were assured of this after we had performed laboratory tests the results of which are given in Table 2 .

Table 2. Comparison of the forecasted and actual temperatures of the fire impact and measured electric resistance of a charcoal specimen

\begin{tabular}{|c|c|c|c|c|}
\hline \multirow{3}{*}{$\begin{array}{l}\text { Time of } \\
\text { standard } \\
\text { fire } \\
\text { impact, } \\
\text { min }\end{array}$} & \multicolumn{4}{|c|}{ Sort of wood } \\
\hline & $\begin{array}{c}\text { Hardwood } \\
\text { (oak, ash) }\end{array}$ & $\begin{array}{l}\text { Softwood } \\
\text { (pine, fir) }\end{array}$ & $\begin{array}{l}\text { Impregn } \\
\text { hardwood }\end{array}$ & $\begin{array}{l}\text { Impregn } \\
\text { softwood }\end{array}$ \\
\hline & \multicolumn{4}{|c|}{$\begin{array}{c}\mathrm{t}^{* /} / \mathrm{t}^{* *} \\
\mathrm{R}(\Omega)\end{array}$} \\
\hline 5 & $\begin{array}{l}605 / 1132, \\
20 \cdot 10^{6}\end{array}$ & $\begin{array}{l}605 / 755, \\
20 \cdot 10^{6}\end{array}$ & $605 /-,-$ & $605 /-,-$ \\
\hline 10 & $\begin{array}{l}680 / 906, \\
15 \cdot 10^{6}\end{array}$ & $\begin{array}{l}680 / 618, \\
7 \cdot 10^{6}\end{array}$ & $\begin{array}{l}680 / 1202, \\
9,6 \cdot 10^{6}\end{array}$ & $\begin{array}{l}680 / 798, \\
13 \cdot 10^{6}\end{array}$ \\
\hline 15 & $\begin{array}{l}750 / 691, \\
10,5 \cdot 10^{6}\end{array}$ & $\begin{array}{l}750 / 633, \\
2 \cdot 10^{5}\end{array}$ & $\begin{array}{l}750 / 1104, \\
7,5 \cdot 10^{5}\end{array}$ & $\begin{array}{l}750 / 752, \\
9 \cdot 10^{5}\end{array}$ \\
\hline 20 & $\begin{array}{l}780 / 758 \\
1,5 \cdot 10^{5}\end{array}$ & $\begin{array}{l}780 / 673, \\
10500\end{array}$ & $\begin{array}{l}780 / 967, \\
2,45 \cdot 10^{5}\end{array}$ & $\begin{array}{l}780 / 710 \\
1,43 \cdot 10^{5}\end{array}$ \\
\hline 25 & $\begin{array}{l}815 / 811, \\
7560\end{array}$ & $\begin{array}{l}815 / 646, \\
8000\end{array}$ & $\begin{array}{l}815 / 830 \\
1,5 \cdot 10^{5}\end{array}$ & $\begin{array}{l}815 / 756, \\
6800\end{array}$ \\
\hline 30 & $\begin{array}{l}840 / 754, \\
5000\end{array}$ & $\begin{array}{l}840 / 641, \\
4000\end{array}$ & $\begin{array}{l}840 / 858, \\
8560\end{array}$ & $\begin{array}{l}840 / 722, \\
4000\end{array}$ \\
\hline 35 & $\begin{array}{l}865 / 717, \\
3450\end{array}$ & $\begin{array}{l}865 / 626, \\
2550\end{array}$ & $\begin{array}{l}865 / 813, \\
4550\end{array}$ & $\begin{array}{l}865 / 730, \\
1550\end{array}$ \\
\hline 45 & $\begin{array}{l}900 / 705, \\
960\end{array}$ & $\begin{array}{l}900 / 619, \\
1050\end{array}$ & $\begin{array}{l}900 / 796, \\
850\end{array}$ & $\begin{array}{l}900 / 701, \\
750\end{array}$ \\
\hline 60 & $\begin{array}{l}945 / 740, \\
143\end{array}$ & $\begin{array}{l}945 / 613, \\
450\end{array}$ & $\begin{array}{l}945 / 818, \\
150\end{array}$ & $\begin{array}{l}945 / 730, \\
150\end{array}$ \\
\hline
\end{tabular}

Note: $\mathrm{t}^{*}$ - actual temperature of standard fire, ${ }^{\circ} \mathrm{C}$; $\mathrm{t}^{* *}$ - forecasted temperature, ${ }^{\circ} \mathrm{C} ; \mathrm{R}$ - electric resistance of a charcoal specimen, $\Omega$.

We can see (Fig 9) that in case of softwood the forecasted time of the fire impact practically tallies with the time of the test standard fire curve, whereas after 60 min of standard fire impact the forecasted fire impact time is equal to $56 \mathrm{~min}$. Meanwhile, in case of hardwood, especially when it is protected by fireproofing compound, the accuracy of the forecast is reduced markedly, whereas after $60 \mathrm{~min}$ of standard fire impact the forecasted fire impact time is equal to $18 \mathrm{~min}$. We can see that a difference of over $40 \mathrm{~min}$ has already been

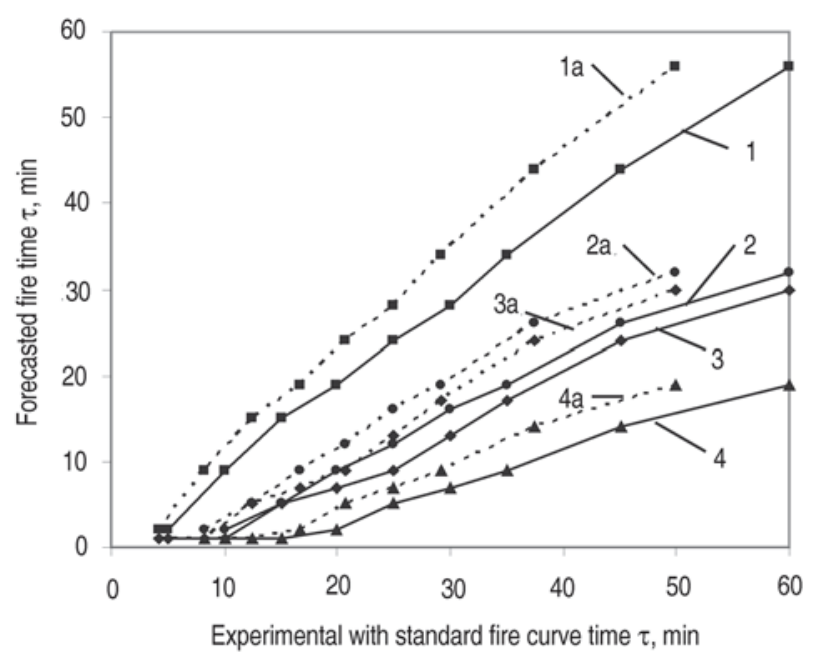

Fig 9. Relationship between the forecast and experimental fire time: 1 - pine, 2 - impregnated pine, 3 - oak, 4 impregnated oak. 1a, 2a, 3a, 4a - the dotted line marks the corrected (by coefficient $\mathrm{k}=1,2$ ) data of the time of impact caused by a standard fire

formed within $60 \mathrm{~min}$. Upon evaluation of the correction coefficient $(\mathrm{k}=1,2)$, it is obvious that the difference between the real impact of fire and the forecast one is too big.

Thus, it becomes clear that the above-mentioned fire origin fixing method is oriented towards analysis of charred hardwood structures which are not processed by fireproofing compounds. When increasing the accuracy of the forecast results for the above-mentioned reason, it is necessary to differentiate the test objects in accordance with the discussed indexes. This necessity is standing out lately with the increase of the fireproofing requirements with reference to wooden structures in Lithuania [29]. Wooden structures in the buildings with higher protection requirements should be fire-resistant, which can be achieved only by protecting them with various fireproofing compounds.

The completed tests have revealed some drawbacks of the instrumental method; therefore, the obtained test results will help to further resolve the problems of reliability of the above-mentioned method.

\section{Conclusions}

1. Tests (investigations) of the influence of the wood density in standard fire tests on the charring rate were inconsistent and contradictory. Irrespective of the fact that wood species that are used for construction in majority of countries distinguish by a narrow density range, a mater pertaining to the united method for calculating the charring rate is problematic and has not been fully settled yet.

2. The performed tests of wood charring rate by applying SBI method, where testing conditions were maximally approached real fire conditions, evidenced the necessity of introduction of the correction coefficient 
$(\mathrm{k}=1,2)$, allowing a more objective evaluation of the amount of oxygen under the testing conditions by forecasting the experimental data of thermal chambers that comply with the conditions as established by ISO 834 .

3 . The performed tests of wood charring of different-type wood, by exposing specimens along the direction of wood growing, evidenced that anisotropy had an influence on the wood charring.

4. The tests helped establish that the effect of the „Flamasep“ and „BAK 1“ fireproofing compounds on the wood charring rate is significant. The protective effect of the fireproofing compounds on softwood is more evident than on hardwood.

5. The instrumental method is sufficiently accurate only in case of softwood (pine, fir) test where the forecast fire impact time practically tallies with the test standard fire curve. Meanwhile, in case of hardwood tests, especially if hardwood is protected with fireproofing compounds, the accuracy of this method is markedly reduced.

6. The performed tests have revealed certain drawbacks of the instrumental method, thus necessitating the differentiation of the test objects in order to obtain a higher accuracy of the forecast results. The obtained test results will help further resolve the problems of reliability of the above-mentioned method.

\section{References}

1. Fedotov, A. I.; Megorski, B. V. Fire-technical expertise (Пожарно-техническая экспертиза). Moscow: VNIIPO, 1978. 210 p. (in Russian).

2. Pofit-Szczepanska, M.; Maloziec, D. Analysis of usefulness of research of electrical resistance of charcoal and char depth to determination the place of origin of fire. In: Intern conf „Badanie przyczyn powstawania pozarow“ 2003 12, Poznan, p. 223-238 (in Polish).

3. Cioni, P.; Croce, P.; Salvatore, W. Assessing fire damage to rc elements. Fire Safety Journal, Vol 36, Issue 2, 2001, p. 181-199.

4. Smirnov, K. P. et al. Complex technique of fire origin fixing (Комплексная методика определения очага пожаpa). Leningrad: VNIIPO, 1986. 114 p. (in Russian).

5. Taubkin, S. I. Fire and explosion, quality of their expertise (Пожар и взрыв, особенности их экспертизы). Moscow: VNIIPO, 1999. 600 p. (in Russian).

6. Standard test methods for fire tests of building construction and materials (ASTM E 119), ASTM, West Conshohocken.

7. ISO 834:1975. Fire-resistance tests - Elements of building products, International Organisation for Standardization, 1975. $25 \mathrm{p}$.

8. Schaffer, E. L. Review of information related to the charring rate of wood. USDA Forest service, Forest Product Laboratory, Res. Note 145, 1966. 25 p.

9. Browne, F. L. Theories of the combustion of wood and its control - a survey of the literature. Report No 2136, USDA Forest service, Forest Product Laboratory, Madison, 1966. 9 p.
10. Hadvig, S. Charring of wood in building fires. Technical University of Denmark, Lyngby, 1981. 153 p.

11. Pofit-Szczepanska, M. The effect of physical properties of the charcoal layer developed when wood is exposed to fire on the heat release rate. In: $25^{\text {th }}$ (Int) Symposium on combustion processes. Irvine $\mathrm{k} / \mathrm{Los}$ Angeles, University California, 31.07-3, 08.1994 (conf. mat.), p. 132-141.

12. Lache, M. Wood combustibility properties. (Abbrandverhalten von Holz). Informationsdienst Holcbautechnik, No 4/91, No 5/91, 1991 (in German).

13. Frangi, A.; Fontana, M. Charring rates and temperature profiles of wood sections. Fire and Materials, Vol 27, Issue 2, 2003, p. 91-102.

14. Syme, D. Verification of charring equations for Australian timbers based on Full-Scale fire resistance tests. In: Pacific Timber Engineering Conf, Vol 1, Queensland Univ. of Technology, Australia, 1994, p. 619-623.

15. Collier, P. C. R. Charring rates of timber. Study report No 42, BRANZ, Judgeford, New Zealand, 1992. 25 p.

16. Harada, K. A review on structural fire resistance. In: $4^{\text {th }}$ Asia-Oceania Symp. on Fire Science \& Technology, Japan Assn. for Fire Science \& Engineering, Tokyo, 2000, p. 155163.

17. Njankouo, J. M.; Dotreppe, J. C.; Franssen, J. M. Experimental study of the charring rate of tropical hardwoods. Fire and Materials, Vol 28, Issue 1, 2004, p. 15-24.

18. White, R. H.; Nordheim, E. V. Charring rate of wood for ASTM E 119 exposure. Fire Technology, Vol 28, Issue 1, 1992, p. 5-30.

19. LST L ENV 1995-1-2:1994. Eurocode 5: Design of timber structures - Part 1-2: General rules - Structural fire design. European Committee for Standardization, Brussels, 1994. 43 p.

20. Schaffer, E. L. Effect of fire-retardant impregnations on wood charring rate. Fire and Flammable, No 1, 1974. 96 p.

21. Lukošius, K. New one side heating method for structures and its application for prediction of fire resistance of structures with separation function (Naujas vienpusis konstrukcijų kaitinimo metodas ir jo taikymas prognozuojant atitvarinių konstrukcijų atsparumą ugniai). Doctoral dissertation, Technological Sciences, Civil Engineering, VGTU, 2004. 100 p. (in Lithuanian).

22. Mačiulaitis, R.; Lipinskas, D. Opportunities of development of the instrumental method applicable in fire research practice in Lithuania. In: The $8^{\text {th }}$ intern conf ,Modern building materials, structures and techniques": selected papers / ed by E. K. Zavadskas, P. Vainiūnas, F. M. Mazzolani. Vilnius: Technika, 2004, p. 979-984.

23. LST EN 13823 SBI. Reaction to fire tests for building products. Building products excluding floorings exposed to the thermal attack by a single burning item (Statybos gaminių degumo bandymai. Statybos gaminiai, išskyrus grindų klojinius, termiškai veikiami vieno degančio objekto). European Committee for Standardization, 2002. 88 p.

24. Butler, C. P. Notes on charring rates in wood. Fire Research Note No 896. Joint Fire Research Organization, Borehamwood, UK, 1971. 18 p.

25. Koczyk, H. Selection of thermophysical properties of heat storage wall. Journal of Civil Engineering and Management, Vol 8, No 4. Vilnius: Technika, 2002, p. 281-285. 
26. White, R. H.; Tran, H. C. Burning rate of solid wood measured in a heat release rate calorimeter. Fire and Materials, Vol 16, Issue 4, 1992, p. 197-205.

27. White, R. H.; Tran, H. C. Charring rate of wood exposed to a constant flux. In: Proc. of wood and fire safety conference, Technical University Zvolen, Slovak Republic, 1996, p. 9-18.

28. Lukošius, K.; Mačiulaitis, R. Calculation methods of high temperatures dividing within the structural components up and their application to fire resistance assessment. Statyba (Civil Engineering), Vol 7, No 5. Vilnius: Technika, 2001, p. 391-396 (in Lithuanian).

29. STR 2.01.04:2004 Essential requirements. Safety in case of fire (Gaisrinè sauga. Pagrindiniai reikalavimai). Certified by Environment Minister of Lithuania, Dec 24, 2003, Order No 704. 35 p. (in Lithuanian).

\section{GAISRO KILIMO VIETOS PROGNOZEI TAIKOMO METODO TOBULINIMO GALIMYBĖS}

\section{Lipinskas, R. Mačiulaitis}

$\mathrm{S}$ a $\mathrm{n} \mathrm{tr}$ a u k a

Tyrimu, kurie atliekami pastatuose po gaisro, pagrindinis tikslas yra išsiaiškinti gaisro kilimo priežasti. Tačiau patikimai nustatyti gaisro priežastị galima tik tuomet, jei bus surasta gaisro kilimo vieta. Būtent tai ir yra vienas sunkiausių gaisro tyrimo klausimu. Šiuo metu Lietuvoje medinėms konstrukcijoms plačiausiai taikomas instrumentinis gaisro kilimo vietos nustatymo metodas, tačiau šiuo metodu gautų rezultatų patikimumas nėra pakankamas, kadangi nepakankamai įvertinamos medienos savybės, jos apsauga antipirenais, gaisro apkrovos dydžio itaka ir pan. Šio darbo tikslas - parodyti, kaip kruopščiai išanalizavus anglèjimo pavyzdžius ir atlikus anglejimo matavimus, galima atlikti gaisro kilimo prognozę. Darbe išnagrinèti anglejjimo greičio ir gylio atvejai, neiprasti anglejjimo pavyzdžiai ir buvo atlikti laboratoriniai tyrimai standartinio ir maksimaliai realaus gaisro sąlygomis, leidžiantys įvertinti gaisro poveikio trukmę, anglejjimo greitị ir kitu gaisro parametrų ịtaką skirtingų rūšių natūralios ir impregnuotos antipirenais medienos bandiniams. Gauti tyrimo rezultatai pravers sprendžiant metodo patikimumo problemą.

Raktažodžiai: gaisro židinys, elektrinè varža, anglies gylis, anglèjimo greitis, patikimumo problemos, antipirenai.

Donatas LIPINSKAS. PhD student. Dept of Labour Safety and Fire Protection. MSc (1999, civil engineer). Research interests: fire investigation, fire resistance of building structures, fire origin prognosis.

Romualdas MAČIULAITIS. Doctor Habil, Professor. Head of Dept of Building Materials. Doctor (technical sciences, 1980). Doctor Habil (technical sciences, 1993). Professor (1999). Research interests: durability, frost resistance, fire prevention and other properties and processes of building materials and products. 